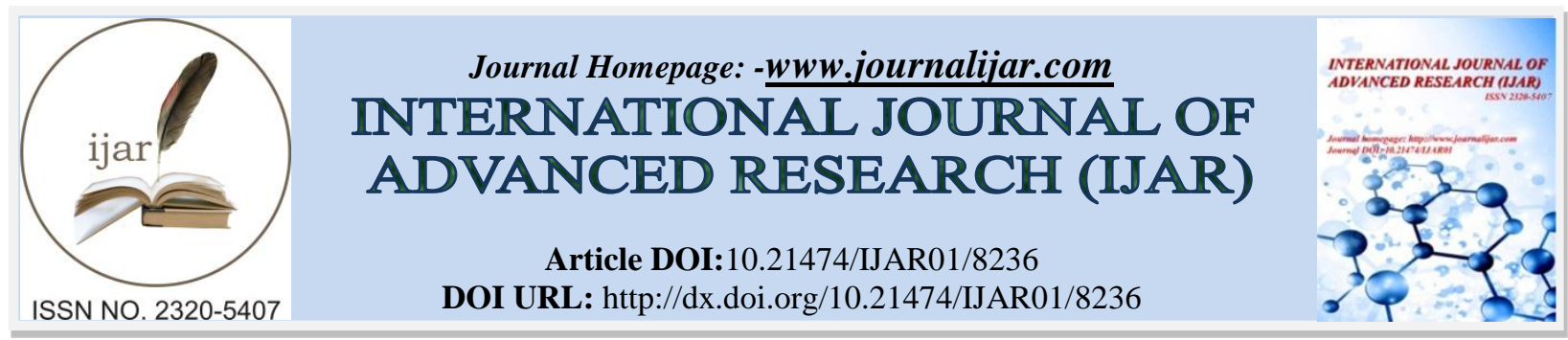

RESEARCH ARTICLE

\title{
UPLAND FARMING PRACTICES BASIS FOR A CULTURALLY-BASED UGMAD TEACHING MODEL.
}

Cris Jhon B. Tejada ${ }^{1}$, Leonisa S. Juarez ${ }^{2}$, Mikkie M. Molbog $^{2}$ and Reynaldo B. Inocian ${ }^{2}$.

1. State Scholars, Social Studies, College of Teacher Education, Cebu Normal University, Cebu City, Philippines, 6000.

2. Director, Institute for Research in Innovative Instructional Delivery (IRIID), Cebu Normal University, Cebu City, Philippines, 6000.

\section{Manuscript Info}

Manuscript History

Received: 18 October 2018

Final Accepted: 20 November 2018

Published: December 2018

Key words:-

Upland farming, culture, planting, organic, inorganic, ugmad teaching model.

\section{Abstract}

This study unveiled the traditional farming practices in the upland areas of Cebu, Philippines and Gunma, Japan during pre-planting, planting, and post planting by identifying the farming methods used; and designing innovative culturally-based Ugmad Teaching Model (UTM) that catapulted the use of traditional farm practices into the art of teaching and learning process. This qualitative study utilized a comparative case study design of a typical farming village in Cebu, Philippines and in Gumna, Japan using a narrative analysis. Unstructured questions were used in a one-on-one interview of the research participants. The upland farming practices were significant and interdependent processes necessary in farm production. Both inorganic and organic farming as well as the basic tools were widely used in Village Farm X; while organic farming and high-tech machineries were commonly used in Village Farm Y which enhanced productivity in preserving the environment that resulted in large chasm between the farming cultures of the two villages. As extrapolated in the study, the UTM was derived as a creative and a culturally-based teaching strategy to fit in the contextualized and localized teaching in the Outcomes-based Education (OBE) curricula.

Copy Right, IJAR, 2017,. All rights reserved.

\section{Introduction:-}

The production of sufficient food today to foster the growing population is the most urgent problem that needs to be addressed in sustainable development. However, a little percentage of this population only produces food for world consumption. Countries in the world find this problem the foremost priority to ensure a better life. The Philippine archipelago is one of the major countries that exports agricultural commodities because of its tropical rainforest climate. It has suitable lands and favorable weather condition for farming. As long as agriculture continues to exist, farmers generate the best crops during the harvest season. The use of synthetic fertilizers and pesticides to produce the most abundant yields has become rampant in the last half of the century and genetic engineering in the last few decades too. With this accord, pesticide-free farms become more popular as an answer to growing awareness of the nutritional and environmental problems. Hence, it is wise to scrutinize some of the cultural practices of farming

Corresponding Author:-Cris Jhon B. Tejada.

Address:- State Scholars, Social Studies, College of Teacher Education, Cebu Normal University, Cebu City. 
before its modern ways are introduced; as these are believed to be the safest ways of planting that have contributed to sustainable development.

Farming customs and traditions appear during preindustrial era by which the forces and energies of nature are linked with spirits or deities that are perceived as superstitions. However, it is difficult to completely distinguish superstitions from the explanations of scientific truths. This study unveils the cultural farming practices in the upland areas during pre-planting, planting, and post-planting. The paper wants to develop a sense of understanding of these farming practices can improve food production and to extrapolate culturally-based teaching and learning model derived from the cultural practices in the farm.

Despite the changes brought by technology in farming from different parts of the world, there are still a great number of farmers who cannot afford to buy machineries and chemicals and still patronize traditional farming because of the negative impacts. The application of chemicals continues to intensify greater production, while gives greater risks to human health. The extensive use of these and its risks to human health condition and to the environment ignite government attention. Nonetheless, the study may contribute in the preservation of traditional forms of farming, its knowledge and practices can balance biodiversity, emend food security, and protect the world's natural resources and improve the people's health conditions. As the millennials tend to ignore the worth of resilient farmers who work hard for the economy, the study also wants them to appreciate their efforts. While this unveils the differences and similarities of upland farming practices in Cebu, Philippines and in Gunma, Japan, the study also seeks to gain insights in Japan's farming practices that may improve Filipino farming strategies in particular.

On the other hand, learning through Western influences prevails mostly in the academic field of teaching. The application of theories for teaching-learning strategies in Eastern perspective is seldom recognized. This application is perceived to be bluntly creditable to offer a culturally vibrant teaching and learning process, which can be modelled as exemplars for contextualized instruction. Despite the skills needed by learners to acquire the four C's in the $21^{\text {st }}$ century (critical thinking, communication, collaboration, and creative thinking), methods and practices of teaching are not accommodated to cater persistent global changes; yet traditional methods still reign to be a dominant way of teaching which leads students to insignificance and boredom.

The findings in the study would help curriculum developers construct a new form of pedagogical design that enhances a comprehensive teaching and learning process to develop a sense of nationalism, pride of place, and national unity, that is generated among the traditional farming practices between the Philippines and Japan. It also contributes to the evolution and proficiency of the twenty-first century competencies that promote the quality of teaching. This contributes to the teachers in local and in international arena to value the usage of domestic cultures in the educational field. This is another way to relive the local culture that is removed within the fabric of the Filipino identity because of colonial mentality and other forms of foreign domination.

As anthropologists think agriculture that makes human life convenient, many do not continue a nomadic life the moment they learn the intricacies of farming. In agriclture, trading, markets, settlements, and towns are formed. Throughout human history, agriculture serves as energy in constructing communities (Huckaby, 2010), to improve a better life. People who work in market industry must find ways to lessen the burden and give a healthy and reasonable price for goods (Huckaby, 2010). To Sofia (2006), a farmland has its own life. Agriculture is the science and art of cultivating the soil that helps the economy since it provides raw materials and products in many industries. Indeed, agriculture serves as the backbone of the economy.

\section{Statement of the Problem:-}

This study unveils the traditional farming practices in the upland areas of Cebu, Philippines and Gunma, Japan during pre-planting, during planting, and post planting by identifying the farming methods used; and designing innovative culturally-based Ugmad Teaching Modelthat catapulted the use of traditional farm practices into the art of teaching and learning process.

\section{Review of Related Literature and Studies:-}

The Traditional Farming for Sustainable Development:-

The goal of sustainable agriculture is to eradicate the dangers in the environment. It focuses more on the long term interest such us maintaining topsoil, biodiversity and rural communities rather than focusing on profit which is just a short term interest (Horrigan, 2002). Less-developed countries have little space to make use of farming technology. 
They prefer hand labor since only a few of them can afford to rent or buy machineries (Loremer, 1999). During ancient times, organic farming has been recognized to have yielded better production. This time, organic farming is needed to provide a sustainable production and a healthy lifestyle (Horrigan, 2002). On the other hand, farmers practicing traditional way of farming have great instinct ability since it is very complex that they can predict favorable harvest, weather condition, crops' behavior and soil conditions and other factors. The organic agriculture in the Philippines is on its way to prove that it can be done at sustainable basis. Safety and protection of health and fertility of soil is a great contribution of organic method for food production (Badgley, 2006). The major aim of chemical-free farming is to boost the nutrition in plant while protecting the land (Pimentel David, 2005).

\section{Conventional Farming:-}

Conventional farming also called as industrial agriculture, is pertaining to a system of farming which embraces the use of chemical fertilizer, herbicides, pesticides and GMO (Ethan, 2016). The aggravation and growth of modern agriculture is the greatest present-day menace to worldwide biodiversity (Hole, 2004). Though conventional farming potentially harms the soil, it makes the crops more fruitful and increase labor efficiency (Reganold, 1986). This nuances support the need for organic farming in farm communities. But prior study showed that organic farming enhances the fertility of the soil compared to conventional farming (Oehl, 2004). Inorganic fertilizer is costly and can damage environment and affects human health (Sofia, 2006). Organic fertilizer is cheap and can contribute to enhance soil fertility. Developing countries tend to have undeveloped agriculture due to the unavailability, expensive machineries, and abrupt adoption of new seeds and methods, which are not suitable for a certain region (Loremer, 1999). Plant breeding is a method which combines possible genes that control desirable trait.

\section{Farming Cultural Practices:-}

Agriculture rituals use sacred symbols like any object, act, event or relation which shows emotion and metaphysical conception (Saavedra \&Mantikayan, 2015). It is considered a way of calling the forces that a society considered important for the control of its subsistence (Friedberg, 1989) and to ensure the existence of bountiful harvest, family and household security over supernatural evils (Hussin, 2008). The indigenous cultures of the Philippines have not been widely known because of the country's Islamization and further Christianization that bring divergent cultural perspectives. Ethnic groups and rural farmers have a particular arrangement of rural conventions that can be portrayed as naturally obtained through the aggregation of encounters, casual examinations and personal comprehension of the earth as the centuries progressed. Huge numbers of these practices are interlaced with their way lifestyle and conviction frameworks (Carating, 2004).

\section{Research Methodology:- \\ Research Design:-}

This study employed a qualitative method using a comparative case study design between the selected farmers of Cebu, Philippines and Gunma, Japan. Unstructured interview questions were used in a one-on-one interview of the research participants to generate the intended verbal data.

\section{Research Environment:-}

The study was conducted in a mountainous farm area of Cebu, Philippines and the equally mountainous farm area of Gunma, Japan.

\section{Research Participants:-}

There were two research participants who served as respondents in the case study from the farming villages in Cebu, Philippines and in Gumna, Japan.

\section{Sampling Technique:-}

A convenience sampling was used because the respondents were selected based on the actual and convenient visit in the farm during the harvest season in Cebu. A separate visit was done in Gunma, Japan on December 23-25, 2017 which was facilitated by a Japanese friend to gather relevant data that served as basis for comparison in a typical farming village in Cebu.

\section{Research Instruments:-}

After the needed thesis statement was conceptualized, the interview guide was constructed based on the identified research concepts. This interview guide was subjected to an inter-rater validation among the social science experts to ensure credibility and dependability of the results. During the actual one-one-interview, the interview guide was 
able to generate the narratives of the research participants. A recorder was used to record their responses. Results of the participant observation were reflected in the field notes. The recorded interviews were transcribed and clustered to determine recurring patterns and themes.

\section{Data Gathering Procedure:-}

After completing the required research protocols, Interview Guide on farming practices consisted the processes and other factors in farming was used in a one-on-one interview for the farmers in Village Farm X in Cebu City, Philippines and in Village Farm Y in Gunma, Japan. Their responses were recorded through an audio-video and field notes. An English-Japanese translator was needed for the interview of a Japanese farmer. The recorded proceedings were transcribed, examined, and categorized to provide a comparison of the farming practices of the two selected locale of the study. A pedagogical framework on a culturally-based teaching and learning process was conceptualized. With this pedagogical framework, the young learners would continuously remember cultural farming practices in a different twist, as these practices were tailored in a classroom community of learners.

\section{Inclusion and Exclusion Criteria:-}

These research participants were selected based on the following criteria: farmers aged 40 and above; had more experience as a farmer; and lived in their present residence for the past 10 years. New and young farmers in the designated research environments aged less than 40; and who lived outside of the identified local were excluded as research participants in the study.

\section{Ethical Considerations:-}

Following the required research protocols, a letter of permission was made and approved by the school heads for the conduct of the study. A separate letter of permission was written to the barangay captain for the approval and the determination of the research participants in one of the mountain barangays in the City of Cebu. On the other hand, an official letter of permission was emailed to a travel agent of Minakami-machi Taiken Ryoko Association (a travel agency to enrich regional economy through sightseeing, interview, including agricultural experience in a farm region) to provide permission on the intent of the study. Through the help of a Japanese friend the permit was handed to a Japanese farmer as the major key informant in Gunma, Japan. To ensure the anonymity of the research participants, their names were held confidential. An Informed Consent was signed by them to prove that they were willing to give worthy information about the study. They were not forced to participate in the interview if it was against their will. The one-on-one interview would be based on their preferred time and place as suggested by the research participants. It was assured that their economic life was not affected. A rapport was built to build friendship and comfortable environment in the actual interview. After the interview, token of appreciation was given to them for helping and sharing relevant information on the conduct of the study. After the transcription of the results of the interview, the research participants were assured that recorded interviews should be mutilated in order to ensure utmost confidentiality.

\section{Results and Discussion:-}

Case 1:-

Village Farm X in Cebu City, Philippines

\section{Pre-planting:-}

Pre-planting is one of the important factors in controlling weeds that can affect seed/plant growth (Hemmati, 2011). Village Farm X has four methods of pre-planting. First is the "hinlo" [cleaning] the area to be farmed through "manipsip" [slash] and "pagsunog" [burn] method to ensure the land is ready for planting and to provide the newly cleared land with nutrients that enhance the fertilization of the crops. This is known as the traditional form of farming known as the "kaingin" or slash-and-burn. It is done through cutting the existing vegetation using sickle and then burning it (Saver, 2018). Second is the "guwad" or "bungkal" [cultivation]. This controls or eliminates the weeds because these compete with the nutrients and moisture with the growing plants (Ness, 2017). The soil is cultivated by using gardening tools called "asarul" [hoe], "daru" [plow], and "pangligwat" [crow bar]. Applying of chemical fertilizer follows. Kaingin system is significant to native clan in upland areas especially to progressing economies (Kleinman, 1995). However, one negative effect of slash and burn is carbon deficit which causes global climate change (Kotto-Same, 1997). 
"Before planting, we cleaned up, we cut the tall grass, and we dumped and burned them. After cleaning up, we removed the shrubs. We sprayed using chemicals to eliminate finally the growing weeds. Then, we tilled the soil using garden tools."(Farmer 1)

\title{
During Planting:-
}

Another process is "pagpugas" or "pagtanum" [planting] in order to produce goods in the market. Bigger seeds like corn, beans, and tubers are directly planted in the garden plot. However, for small seeds like tomatoes, pepper, lettuce, and others undergo "luyong" [growing] in the "luyungan" [seed-box] for a number of weeks in the greenhouse. These are protected in the nursery until when their stems are ready to be uprooted ready to be transplanted in the newly-cleared soil. This protects young plants from pests and diseases until they are completely established before they are transplanted. "Paglalin" [transplanting] is a method of moving a plant from the seed-box to the garden plot (Bareja, 2015) and"puna" [replanting] is a method of replacing the withered young plant with a new one. It requires careful management skills (Elmore, 2013). Applying of chemical fertilizers follows after ten weeks from the day of planting. Another ten weeks to wait, the application of organic fertilizers such as chicken and cow wastes follow.

\begin{abstract}
"When the soil is ready for planting, we plant early in the morning. When it is hot, then we plant before the sundown. We prefer to plant lettuce because it is expensive to assure greater income. Before planting, we have to place the seeds in the seed box in the nursery to ensure its safety. When sprouted seeds grow with at least two leaves, we uproot and replant them in the plot and monitor to replace if there are dead plants in the row. After planting, in ten weeks we nurtured the plants with fertilizers. Another ten weeks to wait, then we fertilize again with chicken wastes or cow dung. We keep on planting after harvest so that we can get back the amount we invested.’(Farmer1)
\end{abstract}

\section{Post Planting:-}

The last process is "ani" or "pamupu" [harvesting], to harvest the yield from the field. The farmers reap the harvests by hand, place in a sack, basket or containers ready for delivery and be sold to the buyers in the market. Though hand-harvesting is costly and requires careful management, it is till advantageous since it can precisely discern the quality of a product at the proper level of maturity and well-trained workers can control minimum destruction to the harvests (Kader, 2002).

"Harvest is dependent with the plant species because there are some that can be harvested earlier and the rest takes time. In most cases, we can harvest within two months after planting. Available middlemen are ready to buy the harvest. This time lettuce is expensive at 20,000 per barrel. But, if there are extra which are not sold out, we sell it per kilos in the locality.'(Farmer1)

\section{Other Determinants:-}

The Philippines have a tropical climate characterized with wet and dry seasons. Top soil and sub soil are the ideal type of soil for planting. Most farmers do not have their own lands. Some only rent and some work under landowners alternately. They still used basic tools in farming. They do not have any technologically advance machineries to make their farming fast and easy because they cannot afford to buy them since they only received little amount from their hard work of planting the whole day while the landowner received abundant amount of money from the farmer's profit and payment for the rent of the land. The consequences of natural phenomenon harm the farmers, which they need equal protection (Philippine Development, 2017).

"When typhoon stikes, all the plants are affected and we cannot do anything on it, soon the plants will die, we wait until the storm is gone and then we plant again. We resort to lending of money from the landlord to defray our daily subsistence, because our capital is gone. We are only tenants of the land we tilled and rented. We own the crops and take care of these; we struggled and requested assistance to help us because our farm area is huge. We paid the assistants. If the price of the harvest is low, we do not profit on it. We worry with our daily subsistence. One of the problems we encounter is on manual labor because of the absence of high-technology. We hire a lot of laborers during harvest season and this additional burden for labor cost. Minus this entire coast, we ended up having a very low income."(Farmer1)

\section{Case 2:-}

The Village Farm Y in Gunma City, Japan 


\section{Pre-planting:-}

The farmers in Japan have four major methods of farming. First is tsuchizukuri, making soil. It is done in December to February (whole winter season) to prepare and fertilize the land for the next planting season. This process includes the putting of fertilizers such as mushrooms, waste of chickens and cows and twigs in the soil. Organic farming is environment-friendly since it aims to avoid environmental problems that are hard to combat with (Trewavas, 2001). It attracts consumers as they are substantially produced without chemical (Darnhofer, 2009. Second is cultivation which happens during early spring in March. It is done by using the tractor to loosen and clean the land. At this time, no weeds and crops are seen because during the winter season most of them withered and died because of less sunlight moreover because of the very cold temperature which is below zero Degrees Celsius (Evangeli, 2014).

"Many students come here and experience this organic farming and crops are very delicious, many were satisfied. Mush room, once mixed with soil, fertilized the land because this is organic. Other than mush room we use waste of chickens and cows as well as dried twigs ...We don't use chemical fertilizers. We use machine for cultivation for a very long time. The bigger rice fields the more difficult to cultivate so other places like Nigata since it has huge rice fields, we use new technology, we use laser. We set the laser in the field and cultivate the soil; the laser controls how deep or narrow level is. However, modern technology was not present before because we just used our instinct and our senses in planting." (Farmer 2)

\section{During Planting:-}

The method of planting happens between the end of spring in May and early summer in June to give farmers the benefit from the farmers' union and help Japan's economy. They use planting machines such as Tueki for planting rice, Japanese's staple food (Marumaya, 2007). Different kinds of methods for different kinds of plants i.e. rice field should be filled with water, scaffolds and etc. for vineyards.

"We used machine for planting. Typhoon and winter are main problems. Here in Minakami no flood, no drought. In winter they cannot do farming." (Farmer 2)

\section{Post Planting:-}

Harvesting happens during early autumn in September and mid-autumn in October. They use harvesters or combine machine to harvest the fruit, vegetables and rice. The farmer's union takes charge in delivering the harvests to be bought by the consumer, since it is the biggest farming organizations in Japan that help farmers sell their crops to the consumers (Godo, 2001).

"Generally when typhoon comes in autumn during August and September season, this happens during the harvest season. If it is a big typhoon it can damage crops. There's no way to protect them because it is natural phenomenon. We cannot control it. After the disaster, the completely damage crops are thrown away, while those which survive are sold in a cheaper price. Natural calamity is a big problem because no products to sell. We use machine for harvest time but harvesting depends on the size of the farmer's farm land, if the size of land is small, they have to pick it by hand. I pick my blue berry by hand but for cultivating and planting I use the machine."(Farmer 2)

\section{On Other Determinants:-}

They have four seasons (winter, spring, summer and fall). They cannot plant anything during winter season. Black soil and red soil are their two major type of soil for planting. They have their own land and machine for cultivation, planting and harvesting. For them, being a farmer alone is not enough to survive therefore; they have business like restaurants and other jobs such as a member of an organization that will pay them to help local and international researchers. The only problem they face is the Farmer's Union. They cannot sell on their own even if they want to because they need clients to buy their own crops which is hard because most of the clients rely in the Farmer's Union. It is the farmers' supplier of fertilizers and equipment. It also supplies other affiliate of different aid such as idea for productivity (Godo, 2001).

“Japanese farmers' income is bigger because the cost of living is high. Living in Japan everything is very expensive. But their profit is not enough for living. Most of the farmers do not have enough income so they are doing another business, like accepting tourist. Farmers do not receive salary, just the profit of their crops. One bad thing is the farmers can do farming business freely, even if difficult, they can because of the support of the Farmer's 
Union...So, because this union is like acompany, they need to profit on their farm so they need to have enough fees. Farmers have to pay regularly to the Farmers' Union.” (Farmer 2)

Case 3:-

\section{Culturally-based Instructional Context}

Tweaking on the realities of the farm to academic instructional context, Ugmad Teaching Model or the UTM exhibits four major steps"hinlo" (kouun), which means clearing out; "guwad" (kouun), which means cultivate; "pugas" (uetsuke), which means to plant; and "ani" (shuukaku), which means to harvest are illustratively created. "Ugmad" is derived from the Cebuano word which means to work for something. As applied into teaching, it is a seamless and dialectical model of instruction that establishes connection from the "hinlo' as the core, as it stretches to the "guwad" and finds its expansion in the "pugas," and reaping the prize of learning in the "ani." It is a modified behaviorist and culturally-based teaching model in which students think to visualize a farm typically in the learning process. As a Reconstructionist Approach, UTM is inclined with the $21^{\text {st }}$ century method of teaching that caters the learners'humanistic needs; while using Behaviorist context of Connectionism Theory of Edward Lee Thorndike that sets the basic elements of dialecticism.

\begin{tabular}{|c|c|c|c|c|}
\hline $\begin{array}{l}\text { Required } \\
\text { Steps of the } \\
\text { UTM }\end{array}$ & Definition & $\begin{array}{l}\text { Instructional } \\
\text { Implications }\end{array}$ & $\begin{array}{l}\text { Anchored on } \\
\text { Connectionism Theory } \\
\text { of Learning }\end{array}$ & Sample Applications \\
\hline 1. Hinlo & $\begin{array}{l}\text { This is the clearing } \\
\text { of weeds in the farm } \\
\text { ready for cultivation }\end{array}$ & $\begin{array}{l}\text { This is mental } \\
\text { conditioning that allows } \\
\text { learners to be prepared } \\
\text { for the intellectual } \\
\text { discussion }\end{array}$ & $\begin{array}{l}\text { Law of Readiness states } \\
\text { that when learners are } \\
\text { prepared to learn more } \\
\text { effectively, then there is } \\
\text { likelihood of } \\
\text { satisfaction }\end{array}$ & $\begin{array}{l}\text { Hinlo is the proper use } \\
\text { of different forms of } \\
\text { motivation or the use } \\
\text { of different techniques } \\
\text { to unlock difficulty }\end{array}$ \\
\hline 2. Guwad & $\begin{array}{l}\text { This is actual tilling } \\
\text { or cultivation of the } \\
\text { soil in preparation } \\
\text { for planting }\end{array}$ & $\begin{array}{l}\text { This is the presentation } \\
\text { and development of the } \\
\text { lesson }\end{array}$ & $\begin{array}{l}\text { Law of Effect states that } \\
\text { when learners find } \\
\text { learning satisfying, then } \\
\text { learning is repeated; but } \\
\text { if learning is annoying, } \\
\text { then it is forgotten }\end{array}$ & $\begin{array}{l}\text { The connection of the } \\
\text { hinlo and the guwad } \\
\text { are well founded. } \\
\text { Lesson are related to } \\
\text { the real life } \\
\text { experiences of the } \\
\text { learners }\end{array}$ \\
\hline 3. Pugas & $\begin{array}{l}\text { This is the planting } \\
\text { of seeds in the } \\
\text { cultivated soil with } \\
\text { proper nourishment. } \\
\text { In the absence of } \\
\text { nourishment, the } \\
\text { planted seeds die. }\end{array}$ & $\begin{array}{l}\text { This is the giving of } \\
\text { insights from whatever } \\
\text { form of instructional } \\
\text { activities provided. } \\
\text { Insights on contents, } \\
\text { feelings, and actions are } \\
\text { recognized }\end{array}$ & $\begin{array}{l}\text { Law of Exercise states } \\
\text { that connection is } \\
\text { strengthen when there is } \\
\text { modifiable connection } \\
\text { between situation and } \\
\text { response (law of use) or } \\
\text { connection is decreased } \\
\text { when there is no } \\
\text { connection between } \\
\text { situation and response } \\
\text { (law of disuse). If the } \\
\text { law of disuse occurs, } \\
\text { then the teachers } \\
\text { provides the puna, as } \\
\text { replacement of the } \\
\text { perceived disconnection }\end{array}$ & $\begin{array}{l}\text { The connection of the } \\
\text { guwad and pugas are } \\
\text { expanded as a form of } \\
\text { learning application. } \\
\text { The students are asked } \\
\text { to find meaningful } \\
\text { connections of the } \\
\text { lesson to other } \\
\text { dimensions of human } \\
\text { life, the society, the } \\
\text { nation, and the world. }\end{array}$ \\
\hline 4. Ani & $\begin{array}{l}\text { This is the harvest } \\
\text { part of the yields of } \\
\text { the farm }\end{array}$ & $\begin{array}{l}\text { This is the part where } \\
\text { students reap what they } \\
\text { have learned from the } \\
\text { lesson through } \\
\text { performance-based } \\
\text { assessment }\end{array}$ & $\begin{array}{l}\text { Different forms of } \\
\text { assessment can be used } \\
\text { as a learning reward; } \\
\text { but not a test on } \\
\text { capacity of the learner }\end{array}$ & $\begin{array}{l}\text { Ani shows the } \\
\text { achievement of the } \\
\text { intended learning } \\
\text { outcomes in a form of } \\
\text { product development, } \\
\text { new invention, and } \\
\text { innovation }\end{array}$ \\
\hline
\end{tabular}




\section{Conclusion:-}

The upland farming practices were significant and interdependent processes necessary in farm production in order to ensure sustainable development. Inorganic and organic farming tools and practices were widely used between the two selected cases. While, Village Farm X in the mountainous area of Cebu City Philippines used the traditional farming; Village $\mathrm{Y}$ in Guman, Japan enhanced productivity in preserving the environment through the use of modern technology that esulted in large chasm of farmers' yield. As extrapolated in the study, the Ugmad Teaching Model was derived as a culturally-based instructional innovation, in order for the young to be reminded about the cultural farm practices in a different twist.

\section{Recommendation:-}

The Philippine government will improve budgetary allocations for the modernization of the farming sectors in the Philippines more especially the small farmers and the tenants. With the Ugmad Teaching Model, it will be further recommended that further studies will be conducted to find out the efficacy of the UTM. School institutions will have to adopt intensive trainings and workshops among stakeholders in order to become adept in its proper execution or implementation to enhance better learning in an outcomes-based education instruction.

\section{References:-}

1. Badgley, J. M.-V. (2006, June 9).Organic Agriculture and the Global Food Supply. Retrieved from https://www.cambridge.org/core/journals/renewable-agriculture-and-food-systems/article/organic-agricultureand-the-global-food-supply/93DD2635AC706B08EE68B881D17A143B

2. Bareja, B. G. (2015, May 9). Methods of Planting Crops: I. What is Direct Seeding and What is Transplanting. Retrieved from https://www.cropsreview.com/methods-of-planting.html

3. Carating, R. B., (2014, August 6). Sustainable Organic Farming in the Philippines: History and Success Stories. Retrieved from https://www.slideshare.net/pd81xz/a-dq96

4. Conventional Farming. (2016) Retrieved from http://www.appropedia.org/Conventional_farming

5. Darnhofer, I.T.-K. (2009, April 8). Conventionalisation of organic farming practices: from structural criteria towards an assessment based on organic principles. A review.Retrieved from https://hal.archivesouvertes.fr/hal-00886488/document

6. Elmore, R. W. (2013, June). Late Planting and Replanting Corn. Retrieved fromhttps://lib.dr.iastate.edu/cropnews/94/

7. Evangeli, A. (2014, June 11). What happens to Plants In Winter? Retrieved from http://www.abc.net.au/science/articles/2014/06/11/4022947.htm

8. Friedberg, C. (1989). Social Relations of Territorial Management in Light of Bunaq Farming Rituals. Retrieved from https://www.jstor.org/stable/27864064?seq=1\#page_scan_tab_contents

9. Godo, Y. (2001, August). openresearch-repository.anu.edu.au. Retrieved from google.com: http://ajrcnet.anu.au/

10. Hemmati E, V. S. (2011). Effect of pre-planting irrigation, maize planting pattern and nitrogen on weed seed bank population.Retrieved from https://www.ncbi.nlm.nih.gov/pubmed/22696965 Hole, D.A. (2004. July 8). Does Organic Farming Benefit Biodiversity?Retrieved from https://pdfs.semanticscholar.org/dfff/66d86ac568792d0628aca0d3c70208e09c38.pdf

11. Horrigan, R. S. (2002, May).How sustainable agriculture can address the environmental and human health harms of industrial agriculture. Retrieved from https://www.ncbi.nlm.nih.gov/pubmed/12003747

12. Huckaby, R. W. (2010). 21st-Century Agriculture. eJOURNALUSA, 13-20.

13. Hussin, H. (2008, December 31). Performing Rice Farming Rituals by Penampang Kadazan of East Malaysia Between Sacred Ritual and Secular Performance. Retrieved from https://jati.um.edu.my/index.php/jati/article/view/6208

14. Kader, A. A. (2002). Postharvest Technology of Horticultural Crops - An Overview from Farm to Fork.Retrieved from HTTPS://UCANR.EDU/DATASTOREFILES/234-2531.PDF

15. Kleinman, D. P. (1995, January 1). The ecological sustainability of slash-and-burn agriculture. Retrieved from https://www.sciencedirect.com/science/article/pii/016788099400531I

16. Kotto-Same, P. J. (1997, November 3).Carbon dynamics in slash-and-burn agriculture and land use alternatives of the humid forest zone in Cameroon. Retrieved from google.com: https://doi.org/10.1016/S01678809(97)00060-1

17. Loremer, L. T. (1999). The New Book of Knowledge. Grolier Inc.

18. Marumaya, K. (2007). Rice Production in Japan. Retrieved from http://www.fao.org/3/a-a1410t.pdf\#page=70 
19. Pleasant, B. (2010, November 26). The Pros and Cons of Cultivating Soil. Retrieved from https://www.growveg.com/guides/the-pros-and-cons-of-cultivating-soil/

20. OEHL, F. (2004, JANUARY 9).IMPACT OF LONG-TERM CONVENTIONAL AND ORGANIC FARMING ON THE DIVERSITY OF ARBUSCULAR MYCORRHIZAL FUNGI.RETRIEVED FROM HTTPS://WWW.NCBI.NLM.NIH.GOV/PUBMED/14714172

21. Philippine Development Plan, 2017-2022.(2017)Retrieved from http://www.neda.gov.ph/wpcontent/uploads/2018/01/Abridged-PDP-2017-2022_Updated-as-of-01052018.pdf

22. Pimentel David, P. H. (2005, July 1). Environmental, Energetic, and Economic Comparisons of Organic and Conventional Farming Systems.Retrieved from https://academic.oup.com/bioscience/article/55/7/573/306755

23. Reganold, J. P. (1987, November 26). Long-term effects of organic and conventional farming on soil erosion. Retrieved from http://adsabs.harvard.edu/abs/1987Natur.330..370R

24. Saavedra, M. \& Mantikayan, E. L. (2015, November 10). Traditional Rice Farming Ritual Practices of the Magindanawn in Southern Philippines.Retrieved from http://www.sciencepublishinggroup.com/journal/paperinfo.aspx?journalid=218\&doi=10.11648/j.ajaf.s.2015030 601.14

25. Sofia, P. K. (2005, May 24). Organic farming-Tradition reinvented. Retrieved from http://nopr.niscair.res.in/bitstream/123456789/6815/1/IJTK\%205\%281\%29\%20\%282006\%29\%20139-142.pdf

26. Trewavas, A. (2001, March 22). Urban Myths of Organic Farming. Retrieved from https://www.researchgate.net/publication/12071462_Urban_Myths_of_Organic_Farming. 